University of Nebraska - Lincoln

DigitalCommons@University of Nebraska - Lincoln

7-1948

\title{
Mississippian-Pennsylvanian Boundary Problems In The Rocky Mountain Region
}

James Steele Williams

United States Geological Survey

Follow this and additional works at: https://digitalcommons.unl.edu/usgsstaffpub

Part of the Earth Sciences Commons

Williams, James Steele, "Mississippian-Pennsylvanian Boundary Problems In The Rocky Mountain Region" (1948). USGS Staff -- Published Research. 502.

https://digitalcommons.unl.edu/usgsstaffpub/502

This Article is brought to you for free and open access by the US Geological Survey at DigitalCommons@University of Nebraska - Lincoln. It has been accepted for inclusion in USGS Staff -- Published Research by an authorized administrator of DigitalCommons@University of Nebraska - Lincoln. 


\title{
MISSISSIPPIAN-PENNSYLVANIAN BOUNDARY PROBLEMS IN THE ROCKY MOUNTAIN REGION ${ }^{x}$
}

\author{
JAMES STEELE WILLIAMS \\ United States Geological Survey
}

\begin{abstract}
A variety of paleontologic and stratigraphic problems are presented by rocks near the MississippianPennsylvanian boundary in the central and northern Rocky Mountains. Stratigraphic sections of these rocks show diverse interpretations of fundamental concepts of stratigraphy and paleontology. In many places where Upper Mississippian rocks directly underlie Pennsylvanian rocks it is difficult to determine the precise location of the boundary between these units. Formations that straddle the boundary are very useful and satisfactory over large areas. Most geologists use various types of lithologic criteria to distinguish formations, but some appear to rely mainly on faunal data, unconformities, or attempts to trace prominent beds. More uniformity in criteria than now exists for the delimitation of formations is desirable. Surface and subsurface formations should conform to the same definition. Critical paleontologic studies of several common species and genera, if based on a large number of specimens, might help solve the boundary problem. More correlations based on several lines of paleontologic evidence and less reliance on a few index fossils would also help. Larger and more varied collections of well-preserved fossils stratigraphically located are needed from critical areas. Additional stratigraphic work in this region should be of a detailed nature and should preferably be done in connection with detailed mapping. Ecologic and paleogeographic factors merit more attention. The age significance of unconformities has perhaps been overestimated generally.
\end{abstract}

\section{INTRODUCTION}

As in many other parts of the United States, the Mississippian and Pennsylvanian rocks of the Rocky Mountain region present many unsolved problems. These problems relate to all stratigraphic zones from the base of the Mississippian to the top of the Pennsylvanian. A group of problems that involve beds at or near the Mississippian-Pennsylvanian boundary are especially interesting because they not only show places at which the geological data are sadly deficient but also involve interpretations and differences in viewpoints on fundamental principles of paleontology and stratigraphy.

All students of Carboniferous problems, especially those who have themselves worked in the Rocky Mountains, will agree that much geologic work needs to be done there. The type of work most needed, in the writer's opinion, is not, however, reconnaissance work but detailed work, whereby the investigator be-

I Published by permission of the Director, U.S. Geological Survey. Manuscript received February 24, I948. comes well informed on a single small problem or spends considerable time on a large problem. There is, however, also room for broadly interpretive work. Considering the vast area of the Rocky Mountains underlain by Carboniferous rocks and the difficulty of access of many of the exposures, a very creditable amount of knowledge of the stratigraphy and paleontology has existed for a long time; but not all of it is published, and much that is published is in papers concerned also with general and economic geology, with which papers many stratigraphers appear to be unfamiliar. This knowledge must be considered by anyone starting work in the Rocky Mountains.

Problems in the Rocky Mountain Carboniferous (not all of which will be solved or even reviewed in this paper!) range from the need for more and better fossils, carefully collected with respect to their geographic locations and stratigraphic horizons, to the need for reviews, and perhaps reappraisals, of some of the fundamental hypotheses and definitions used in stratigraphy and paleontology. 
Among these last-named are such things as definitions of various rock and time units and the applications of these definitions in the field; hypotheses of, and factors in, the correlation of strata; and theories of species definition in paleontology. Despite the two hundred and thirty or more years of the existence of the science of stratigraphy and stratigraphic paleontology, many disagreements exist in the application, if not in the definition, of many of the fundamental or near-fundamental concepts upon which the daily work of the stratigrapher and stratigraphic paleontologist is based.

Whether one considers the Mississippian-Pennsylvanian boundary a systemic, subsystemic, or series boundary depends on the definitions of a system, a subsystem, and a series to which one subscribes and on the applications (or interpretations) of these definitions in particular regions and with particular sequences of rocks; also involved are the uses or underlying purposes that one has in mind for each of the units, the general usage throughout the world, the degree of reliance and degree of fineness of intercontinental correlations of the particular units of rocks under consideration, and the breadth of experience one has with the rocks involved. All these are variable, and there is certainly adequate room for justified disagreements in the weights and interpretations given each of the above factors and for disagreement in the rank assigned to the units called "Mississippian" and "Pennsylvanian." A definite agreement is not necessary, and it would be outside the scope of this paper to present arguments for or against any specific conclusion. The writer considers that the Mississippian-Pennsylvanian boundary is an important boundary in the United States (more so in some regions than in others) and believes it to be an important time and time-rock boundary, as distinct from a lithologic boundary. It may (and does) happen to coincide with distinct lithologic changes in some places but not with important lithologic changes in others. It coincides with an unconformity in some regions and not with a recognizable unconformity in others. It is a practical boundary for mapping in some places, and in others it is not. Nevertheless, this boundary is one of the more important ones in the United States.

\section{POSITION OF MISSISSIPPIAN-PENN-} SYLVANIAN BOUNDARY

All who are familiar with the general geology of the central and northern Rocky Mountains know that, broadly speaking, the Mississippian rocks there constitute a sequence mainly of limestones, whereas the Pennsylvanian rocks constitute a dominantly sandstone or "quartzite" sequence. Between the dominantly limestone sequence of the Mississippian and the dominantly sandstone sequence of the Pennsylvanian there lies a series of thin and in many places alternating beds of sandstones, shales, thin limestones, cherts, and other kinds of rock. In many places this series of rocks contains red or purple beds, material from which stains associated beds and at many exposures the whole series has a reddish tinge. In many places the Mississippian-Pennsylvanian boundary is within this series of rocks, some of the beds being Mississippian and others Pennsylvanian. In other places, however, the Mississippian-Pennsylvanian boundary, as determined by fossils, appears to coincide with a lithologic boundary. The Mississippian-Pennsylvanian boundary is placed within a series of alternating thin-bedded rocks - a nonresistant series -not only in the area here discussed but 
in a far wider area in the western part of the United States.

\section{FORMATIONS INVOLVED}

Early practice.-The variable beds between the Mississippian limestones and the Pennsylvanian sandstones or quartzites have, in the area under discussion, been placed in different formations in different parts of the area. In western and central Montana and in northwestern Wyoming they were generally assigned to the lower part of the Quadrant formation and widely, but not universally, considered Mississippian in age. In westcentral and central-northern Wyoming and in parts of Montana contiguous to northern Wyoming, they were placed in the Amsden formation, which has from I906 (Darton, I906, p. 5), two years after the time of the proposal of the name "Amsden" for the beds, been generally considered to be of both Mississippian and Pennsylvanian age. In southeastern and eastern Idaho and contiguous parts of western Wyoming and Utah, the lower beds of the sequence were for a long time placed in the upper part of the Brazer limestone and the upper beds in the lower part of the Wells formation. In mapping begun in I93I in the Afton quadrangle, southeastern Idaho and southern Wyoming, but as yet unpublished, W. W. Rubey and the writer grouped the beds together in a single mapping unit, to which a field name has been applied pending decision as to which of the available names to use. In north-central Utah the beds were put in the Morgan formation, which was considered by its namer, Eliot Blackwelder (I9Iо, p. 530), to be Pennsylvanian in age, but which may contain Mississippian beds in its lower part. The writer has collected Pennsylvanian fossils from the type section and other exposures of the Morgan, and
Mississippian fossils from beds that might be considered Lower Morgan. The name "Morgan" has been extended into the Cottonwood-American Fork region of the Wasatch Mountains and to other areas in this part of the Wasatch Mountains and has also been used at several places in the Uinta Mountains.

In central-western Utah, the nonresistant unit of alternating shales, limestones, and sandstones in which the Mississippian-Pennsylvanian boundary occurs has little red material. At this place the unit was called the Manning Canyon shale by Gilluly (1932, pp. 3I-34). The name Manning Canyon has been used also for units of approximately the same age in eastern Nevada and at other places in central Utah, including at least one area in the Wasatch Mountains, near Provo (Baker, I947).

The above paragraphs give the general usage as of about I930 (fig. I). This shows that in most places the MississippianPennsylvanian boundary was frankly acknowledged not to be a practical mapping (i.e., formational) boundary but to lie within a formation. Exceptions to this were found, however, in the southeastern Idaho area, where attempts (abandoned by $\mathrm{W}$. W. Rubey and the writer) were made to map the Mississippian-Pennsylvanian contact as the Brazer-Wells contact and, to a degree, in the area of the typical Morgan formation, where all of the Morgan was considered to be of Pennsylvanian age.

Recent work.-Much work has been done in the central and northern Rocky Mountains since 1930. The United States Geological Survey has had many field parties working in various parts of the region. Renewed interest in stratigraphic problems has been shown by some of the state geological organizations and especially by geologists on the faculties of col- 
leges and universities in the area. Very important contributions have been made by the faculties and student bodies of the many summer camps maintained by midwestern and eastern universities in different parts of the Rocky Mountains. some of the identifications are as yet provisional. Most of the sections measured by Geological Survey parties have been published. Unfortunately, wartime and other duties have prevented the writer from compiling and publishing many of

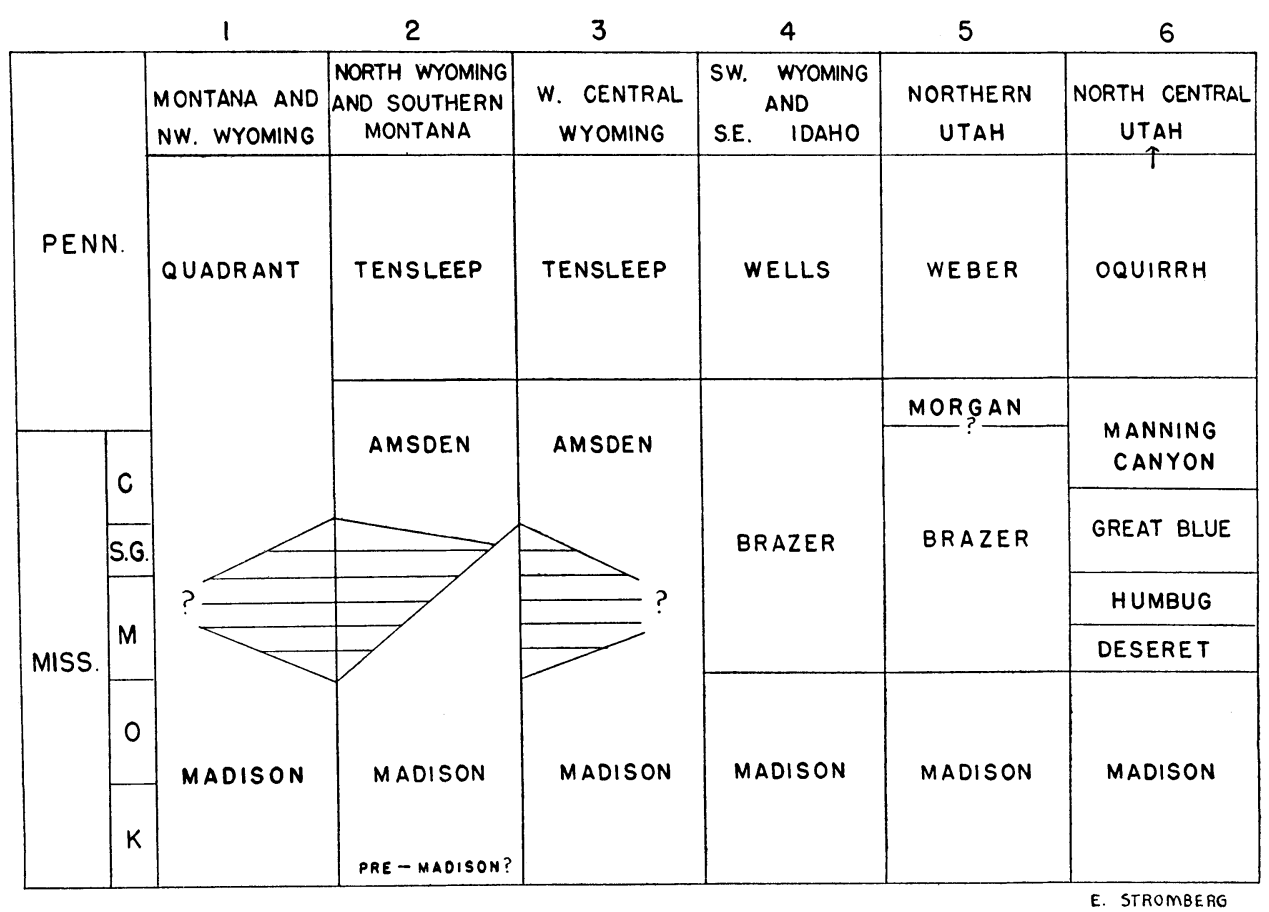

FIG. I.-Correlation chart showing widespread usage as of about r930. The stratigraphic usage shown for several of the areas on the chart is still the preferred and most satisfactory, but it has changed in other areas. The diagonal lines at the base and top of the cross-lined areas represent an attempt to show that both the top of the Madison limestone and the base of the Amsden formation probably are of different ages in different places, or are thought to be by different geologists. The abbreviations are for the well-known Mississippi Valley subdivisions of the Mississippian.

The writer has aided nearly every United States Geological Survey party that has worked in this area since I930 with its problems in Carboniferous rocks and, in addition, while engaged in stratigraphic projects of his own, has measured many sections in areas not worked in detail by the Survey mapping parties. Fossils have been systematically, though not always adequately, collected from nearly all these sections, and most of these have been identified, although the sections that he has measured independently and from studying carefully all the collections of fossils in his hands.

\section{SELECTED STRATIGRAPHIC SECTIONS}

The total stratigraphic work done on the Mississippian-Pennsylvanian boundary problem by all the geologists who have worked in this region is so great and the number of stratigraphic sections is so large that only a small proportion of them can be discussed in this paper. Con- 
sequently, a few sections have been selected to show the trends in each of several areas. It is hoped that these sections will reveal general tendencies in procedure that can be evaluated later and will show some of the specific deficiencies of knowledge, disagreements in philosophies, and other problems that exist in connection with the stratigraphy and paleontology of the Mississippian-Pennsylvanian boundary in the Rocky Mountains. The sections given here were selected because they are more or less typical of the areas or because they show fossil occurrences, lithologic features, or terminology that the writer believes are of interest. The writer has personally visited the area of each section cited from the various publications. Several of the sections have been examined in the field with the men who measured them.

\section{SECTION IN THE BIG SNOWY MOUNTAINS CENTRAL MONTANA}

The section in the Big Snowy Mountains of central Montana (sec. I, fig. 2) is condensed from one published by Scott in 1935 (p. I024). It is given to indicate changes in usage that have gained wide acceptance in a part of the area where the nonresistant alternating beds were for a long time placed in the Quadrant formation. The locality is "on north flank of Big Snowy Mountains, sec. 6, T. I2 N., R. 20 E."

Reeves in I93I (p. I40) recognized four units in the Quadrant formation which he described as follows: (I) an upper thin-bedded fossiliferous limestone interbedded with red shale, I00-200 feet thick; (2) a unit of red, brown, and black shales and cross-bedded sandstones, 300400 feet thick; (3) a 500-foot unit of variegated calcareous shale, with a few thin limestones and including a predominantly green shale near the middle;
(4) a basal unit of yellow sandstone, sandy shale, and gypsum, I50-200 feet thick. Girty, who examined the fossil collections made by Reeves, identified fossils from the middle and lower part of the upper limestone unit that, though not definitely diagnostic, were considered to be upper Mississippian in age (either Ste. Genevieve or Chester or both), but he considered a collection from near the top of this limestone unit at another place to be clearly Pottsville (Pennsylvanian). The writer has collections from this limestone, but he has not yet been able to study them or to re-examine Girty's collections.

The main sandstone or quartzite, to which the name "Quadrant" is now generally restricted and which is probably younger than any of the beds in Reeves's section, is represented only by a few outliers, if at all, in the Big Snowy area, but considerable thicknesses of this sandstone occur in other parts of Montana. In many places Jurassic beds rest on Reeves's upper thin-bedded limestone of the Quadrant formation. In 1935, Scott described some fifteen or more stratigraphic sections in Montana, including the one here cited in the Big Snowy Mountains. Like Reeves, he divided the Quadrant into four units in the Big Snowies, but his units did not coincide precisely with those of Reeves. For his two lower units he brought in the names Kibbey and Otter, names used by Weed for members of the Quadrant in the Little Belt Mountains. To a unit composed in large part of "black petroliferous shales and sandstones" immediately below the upper limestone unit of Reeves, he gave the name Heath formation. For the upper limestone unit he brought in Darton's (I904, p. 396) Amsden from central-northern Wyoming. Scott considered the Kibbey, Otter, and 


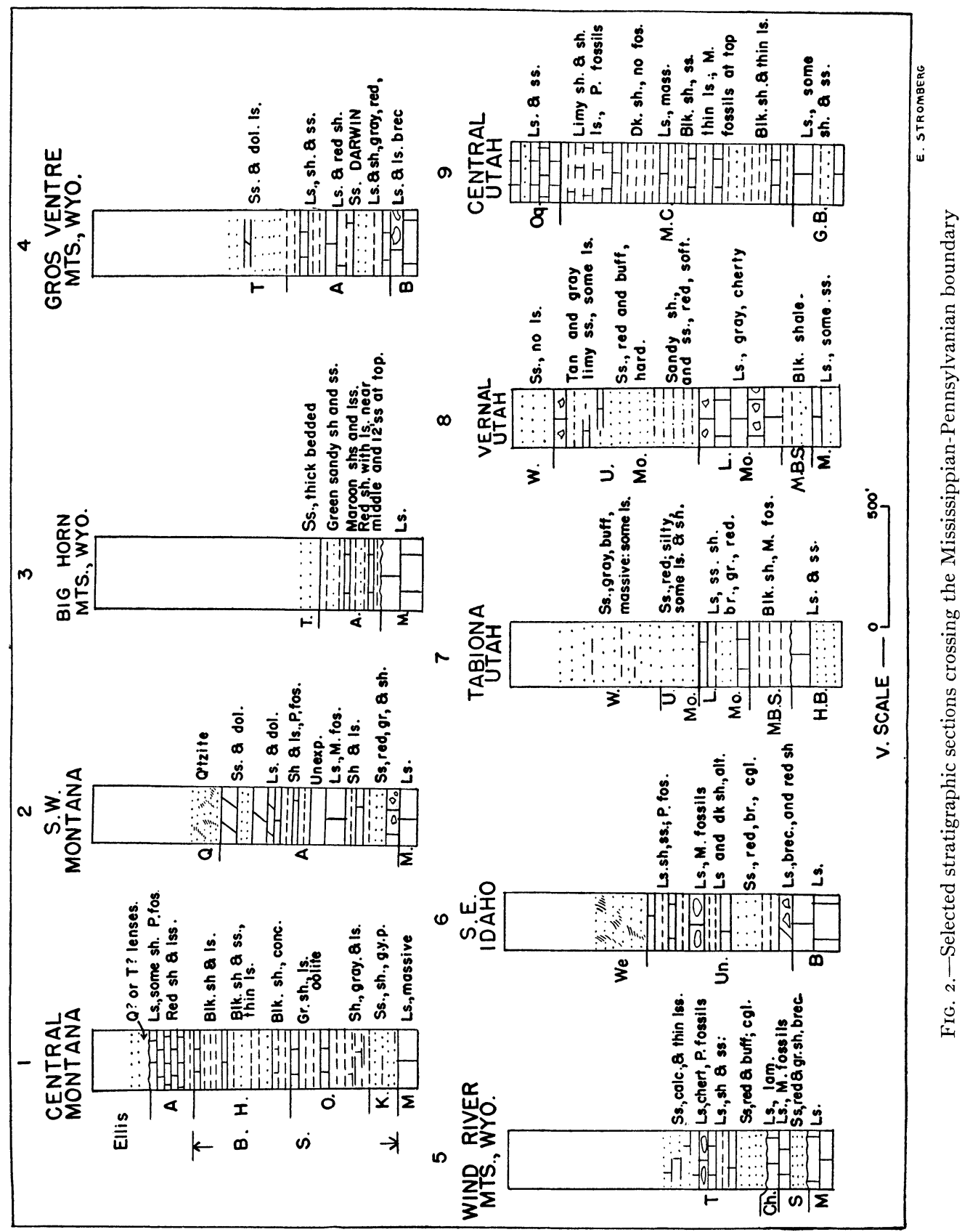


Heath to be of formational rank and to belong to a group to which he applied the name Big Snowy group. Evidence from several classes of fossils published by different investigators has confirmed the Upper Mississippian age of the Big Snowy group and has suggested correlations of specific units with other units in the Mid-Continent region. The age of the Amsden of Scott of this region is not, however, firmly established. As stated earlier, Girty identified some of the faunules from it as upper Mississippian and others as Pennsylvanian. Scott in I935 (p. I032) considered the unit that he called Amsden in the Big Snowy Mountains to be of Mississippian age. Later in 1945 (1945a, p. I195; I945b, p. I I96), he assigned the Amsden of central Montana to the Pennsylvanian not only because, presumably, of a big overlap at its base that he had recognized in I935 but also because, mainly, of the presence of certain species of Millerella in it. Other microfossils occur in the Amsden, but those so far identified are not definitely diagnostic. Though Millerella was for a time thought to be only of lowest Pennsylvanian age, it now is known to have a long range, which includes Mississippian as well as late Pennsylvanian, and some paleontologists maintain that species of Millerella are not yet safe zone markers. Perry and Sloss in 1943 (p. I 293) also described an overlap at the base of the Amsden, but they considered the Ams- den to be both upper Mississippian and lower Pennsylvanian. The overlap, according to them, would then have occurred in upper Mississippian time. Thom and others have mentioned some evidence of physical unconformity at the base of the Amsden. Perry and Sloss also describe an unconformity at the base of the Big Snowy group, with sandstones of the Kibbey formation filling channels and solution cavities some 300 feet below the top of the Madison limestone. On the other hand, Scott (I935), Perry (1937), Pardee (I937), and others suggest an unconformity above the Amsden formation in Montana.

The three units that make up Scott's Big Snowy group have been mapped as formations in several places in Montana and have been recognized in subsurface as far east as the Dakotas and northward into Canada. The variations in thickness and paleogeography of these units are shown on maps by Perry and Sloss (1943). The Charles formation, proposed by Seager as part of the Big Snowy group below the Kibbey, has not yet gained wide recognition in surface work. The validity of Scott's use of the Kibbey, Heath, and Otter as formations would seem to the writer to be established either on the surface or in subsurface in those areas where each has sufficient thickness and distinction to qualify it as a mappable lithologic unit on the scales ordinarily used for topographic quadrangle

\section{Explanation of Figure 2}

The sections of figure 2 were selected to show interesting fossil occurrences, lithologic features, and stratigraphic terminology. Many of them are condensed in order that they may be shown together on one figure. The references are given in connection with the discussions of the sections on pp. $33 \mathrm{I}-340$. Only small parts of the lowest and uppermost formations in each of the sections are shown.

The following are the names for which the abbreviations in the respective sections stand: $I: B . S$., Big Snowy group; $Q$ ?, Quadrant?; $T$ ?, Tensleep?; $A$, Amsden; $H$, Heath; $O$, Otter; $K$, Kibbey; $M$, Madison. 2: $Q$, Quadrant; $A$, Amsden; $M$, Madison. 3: $T$, Tensleep; $A$, Amsden; $M$, Madison. 4: $T$, Tensleep; $A$, Amsden; $B$, Brazer. $5: T$, Tensleep; $C h$, Chester; $S$, Sacajawea; $M$, Madison. $6: W e$, Wells; $U n$, unnamed beds; $B$, Brazer. $7: W$, Weber; U. Mo., Upper Morgan; L. Mo, Lower Morgan; M.B.S., Mississippian black shale; H.B., Humbug. 8: W., Weber; U. Mo., Upper Morgan; L. Mo., Lower Morgan; M.B.S., Mississippian black shale; $M$, Mississippian. g: Oq., Oquirrh; M.C., Manning Canyon; G.B., Great Blue. 
work in the area in which it occurs. In other places these units would, if recognizable, be reduced to member or bed status. In this last alternative the question arises as to what formation they would be referred as members - an enlarged Amsden formation, a Big Snowy formation, or an entirely new formation. Terminology used in sections measured by Gardner, Hendricks, Hadley, and Rogers (I945) of the United States Geological Survey, suggests that the Kibbey, Otter, and Heath lose their identity, at least as formations, in short distances. This seems so because in some areas that are near the stratigraphic sections in which these authors recognize Scott's formations-Kibbey, Otter, and Heaththe same authors place all the beds between the Madison and the Quadrant in the Amsden. The Amsden as thus used may or may not contain equivalents of the Kibbey, Otter, and Heath. Some would maintain that these three units have pinched out and been overlapped by the Amsden. Another interpretation would be that the Kibbey, Otter, and Heath in some areas contain lenticular beds that change laterally so that the formations soon lose their identity in these areas. The apparent increase in thickness of the Amsden in places where the formations of the Big Snowy group are not recognizable and the Amsden is the only formation between the Madison and the Quadrant would favor the last interpretation. Unfortunately, fossils so far obtained are inadequate to solve this problem.

SECTION IN SOUTHWESTERN MONTANA

Section 2 of figure 2 is a section taken from those published by Gardner, Hendricks, Hadley, Rogers, and Sloss (I946), mentioned above. The section is condensed for graphic representation.
The location is near Sappington, southwestern Montana, in Sappington Canyon, in Section 25, T. I N., R. 2 W., about i4 miles southwest of Three Forks and about $35^{-40}$ miles southwest of the Big Snowy Mountains. The formations shown are the Madison, the Amsden, and the Quadrant. A limestone breccia at the base of the Amsden formation suggests an unconformity. L. L. Sloss has identified Mississippian fossils, including Diaphragmus, from the lowest thick limestone unit shown in the Amsden of the section and Pennsylvanian fossils from a series of siltstones, 50-100 feet above the top of the limestone that bears Mississippian fossils. The top of the Amsden formation is here drawn at the top of the nonresistant beds, and a considerable thickness of alternating sandstones and dolomites is included in the Amsden. The uniformity in lithology of the Quadrant seems to have been the deciding factor in delineating it as a formation and in distinguishing it from the Amsden, which is recognized by its heterogeneity in composition and nonresistant character.

\section{SECTION IN THE BIG HORN MOUNTAINS, WYOMING}

Section 3 of figure 2, from the Big Horn Mountains, is condensed from one measured by Darton (Igo6, p. 5) in the canyon of Little Tongue River, Dayton quadrangle, Wyoming. This section was selected because it is only about 6 miles from the type locality of the Amsden formation. The type locality is given by Darton (1904, p. 396), who defined the formations as the Amsden Branch of Tongue River, about 5 miles southwest of Dayton, in the Dayton quadrangle, $\mathrm{Wy}$ oming. As shown in the figure, some of the thicknesses are slightly exaggerated. The total thickness of the Amsden is Igo feet. The terminology, which is that of 
Darton, is widely used in this region at the present time. Judging from C. C. Branson's (1939, pp. I 202-I 213) usage in sections in the Big Horn Mountains, probably some of the lower beds of Darton's section, possibly those up to the base of the 12 -foot sandstone, would be included by him in his Sacajawea, or in other beds referred by him to the Mississippian. The typical area of Branson's Sacajawea formation, discussed later in this paper, is in the Wind River Mountains. To the writer's knowledge, Branson has not cited faunal evidence for extending it into the Big Horn Mountains, so presumably the extension was based mainly on lithology. No specific lithologic features, however, have been given to explain the extension or to furnish criteria for the lithologic differentiation of the Sacajawea from overlying beds.

In the Big Horn Mountains, the Amsden is a variable formation, both in thickness and in lithology. Because of the thickening and thinning of many beds in short distances, one suspects that at some stratigraphic zones they are lenticular. In several places the basal bed is a sandstone, which may attain a thickness of as much as roo feet or more, but sandstones occur at several stratigraphic positions in the Amsden of most areas. In a section measured by the writer in I920, along Little Goose Creek, about 25 miles southeast of the type locality, a thinbedded sandy limestone that is dense to finely crystalline and has a purplish cast was considered the basal bed of the Amsden.

The contact with the underlying Madison limestone in this region in many places is irregular, and shales from the Amsden fill depressions some of which are probably sinkholes in the Madison.

The writer knows of no fossils from the type locality of the Amsden, but in print fossils have been reported from the Amsden of the Big Horn Mountains from several localities. The writer has collected them from other localities in the Big Horns. The presence of fossils of probable Carboniferous age from the upper part of the Amsden was mentioned by Darton (1904) in his original description of the formation. Pennsylvanian fossils from the Amsden have since been listed in many United States Geological Survey papers and in other publications. Some of these fossil lists were brought together by C. C. Branson in I939. Fossils are not abundant in the lower part of the Amsden of the Big Horn Mountains; but, in Igo6, Darton (p. 5) mentioned the occurrence of a coral identified by Girty as Menophyllum excavatum Girty and fragments of a Spirifer and a "Zaphrentis" from a limestone bed in the lower part of the Amsden near Soldier Creek, some I $5^{-20}$ miles southwest of the type locality. Girty believed that these suggested Mississippian age for the lower Amsden; and the Amsden in this general area has for a long time been generally considered to contain both Mississippian and Pennsylvanian beds. The writer does not consider these fossils of themselves adequate to establish a Mississippian age for the lower part of the Amsden; but the absence of definite Pennsylvanian fossils near the base of the Amsden in the Big Horn Mountains and the presence of Mississippian fossils in the alternating series of beds between the Madison limestone and the Quadrant (Tensleep) formation north and west of the Big Horns in Montana and south and west of them in central Wyoming strengthen considerably the meager fossil evidence for a Mississippian age of the lower Amsden in the Big Horns. If definite stratigraphic tracing could show that the lowest beds of the Amsden of the Big Horns were 
younger than the youngest near-by beds with Mississippian fossils, it would be an argument for the absence of Mississippian beds in the Big Horn Mountains, but this does not appear to be possible because of the areas of younger rocks between the mountain ranges. From time to time, verbal reports are made of the discovery of Pennsylvanian fossils in the basal Amsden of the Big Horns, but the writer does not know of any published record. Collections from the Amsden made in conjunction with field work in the Big Horns and mountains west of the Big Horn Basin by W. G. Pierce and D. A. Andrews and the writer have not yet been carefully studied.

In the Big Horn Mountains the sandstone near the base of the Amsden has been identified by some geologists as the Darwin sandstone member, whose type locality is in the Gros Ventre Mountains. This identification appears to be based on lithologic similarity and similar position in the stratigraphic succession. Some geologists would place the Mississippian-Pennsylvanian boundary at the base of the Darwin sandstone, not only in the Gros Ventres, but in other areas where they believe the Darwin can be recognized. Such an interpretation would not give a boundary closely tied to faunal data, as diagnostic fossils are not known from beds near this boundary. The practical advantages in mapping a unit boundary at the base of a prominent sandstone where that sandstone can be definitely identified are easily understood; but to assume without faunal data that such a boundary is a period or epoch boundary seems to the writer to be unjustified, even though an unconformity might be present. To use the base of the Darwin sandstone unit as the base of the Amsden, even if that sandstone can be definitely identified from section to section, would add still another type of lithologic criteria to those used elsewhere for the base of the Amsden, as there are several feet of nonresistant alternating shaly beds below the Darwin, or so-called "Darwin," at many places. The Amsden in many different places in the Big Horn Mountains and Big Horn Basin and at other places in Wyoming has been described and mapped by many geologists. Most geologists have considered it in part Mississippian and in part Pennsylvanian, but in local areas it has been referred entirely to the Pennsylvanian, and in a few areas, notably in the Wind River Mountains, it has been referred by a few geologists entirely to the Mississippian. Those who have placed the Amsden wholly in either the Mississippian or the Pennsylvanian have not cited definite fossil evidence from critical beds.

\section{SECTION IN THE GROS VENTRE MOUNTAINS, WYOMING}

The section selected from the Gros Ventre area (sec. 4 in fig. 2) was measured by Wanless and Bachrach and published in 1947 by Helen L. Foster (p. I557). The locality is north of Sheep Creek in the N.E. $\frac{1}{4}$, Section Io, T. 42 N., R. II5 W., Teton County, Wyoming. This locality is near the type area of the Darwin sandstone. Miss Foster designates the beds above the Darwin as upper Amsden; those below it as lower Amsden. The Darwin sandstone in this section is given as 97 feet thick, but its thickness varies in the surrounding region. The Amsden formation was examined briefly by the writer last summer at one locality in the Gros Ventres. The beds below the Darwin, in the lower part of the Amsden, consist of red shales, gray, pink, and lavender fine-grained limestones, and beds of chert. No fossil names were listed by Miss Foster, but she states that her "lower Amsden" contains fossils resembling both Mississip- 
pian and Pennsylvanian types. She believes that the Mississippian-Pennsylvanian boundary is near the base of the Darwin. In connection with studies in this area by Eliot Blackwelder, C. W. Tomlinson, and other geologists of the United States Geological Survey in I9I I and in near-by areas in subsequent years, Dr. G. H. Girty examined many collections of fossils from beds referred to the Amsden. Lists from two different stratigraphic zones are published in Blackwelder's paper (1913, p. I76). The list for the uppermost zone, which is said to be from a thin group of limestone beds a little below the middle of the formation, shows the zone clearly to be Pennsylvanian. The fossils from a zone 60 feet lower are not so diagnostic but appear to the writer to be also Pennsylvanian. Girty, however, reserves the possibility that they may be Mississippian. There has not been an opportunity for the writer to re-examine the actual collections or to study Blackwelder's field notes. Neither collection is located stratigraphically with respect to the Darwin sandstone, but it is probable that both came from beds above it. This cannot, however, be definitely stated. The United States Geological Survey has had a field party working in the Gros Ventres during the past season, and several universities have had students and faculty members working there in recent summers. It is to be hoped that the examination of fossils obtained by these investigators will soon supply some definite faunal data on the age of the Darwin sandstone member of the Amsden.

SECTION IN THE WIND RIVER MOUNTAINS, WYOMING

Section 5 , figure 2 , shows relationships of the strata in the Wind River Mountains. The section was described by C. C. Branson in 1937 (p. 65I), but the ter- minology is taken from a I939 publication (pp. I 209-I 210) showing the same beds. The locality is Bull Lake Creek. In his 1937 paper, Branson proposed to split the sequence that had previously been generally called Amsden into three units. The lowest of his three units consisted of 43 feet of cherty limestone underlain by 2-I I feet of "red and buff sandstone and shaly sandstone, breccia in places, shale cave filling in places." The 43 -foot limestone is the zone of the invertebrate fauna described by E. B. Branson and D. K. Greger in I9I8 (pp. 309-326) as of Ste. Genevieve age. For this lower unit of limestone and underlying red rocks Carl Branson proposed formation rank and gave them the name "Sacajawea formation." One of the reasons for giving these beds formation rank appears to have been that they were Mississippian, whereas the upper beds of the Amsden were Pennsylvanian. C. C. Branson considered the Sacajawea formation to range possibly from Salem to Ste. Genevieve age. He thus considered it pre-Chester. Beds that Branson probably would refer to the Sacajawea have been examined at several localities by the writer, but they contain very few fossils or none at all. Aside from the faunas described by E. B. Branson and Greger and by C. C. Branson in his 1937 paper, ostracodes have been described by Morey (I935, pp. 474482 ) and by Croneis and Funkhauser (I938, pp. 331-360). These last two consider the ostracodes examined by them to be Chester.

Above the Sacajawea formation is a series of limestones about 6o feet thick that C. C. Branson believes is Mississippian, probably Chester, but few fossils have been found in it or, if found, have not been reported in publications. Above the limestone beds is a sandstone 80 feet thick that has been identified by some geologists as the Darwin sandstone. The 
Mississippian-Pennsylvanian boundary is drawn at the base of this sandstone by some investigators; but, as elsewhere, there is little direct paleontologic evidence for its precise location at the base of the Darwin. Pennsylvanian fossils have been collected from a limestone some 80 feet above the top of the sandstone. Other geologists have rejected Branson's proposed Sacajawea formation on the grounds that in actual field practice it is not a mappable unit over an appreciable area. They have mapped the entire sequence of variable nonresistant beds between the Madison and Tensleep formations as the Amsden formation and have not ventured to indicate the precise location of the Mississippian-Pennsylvanian boundary within the Amsden. Some of these geologists have recognized the Darwin as a member of the Amsden. C. C. Branson, in 1939, proposed dropping the name Amsden. He would include in the Tensleep formation all those beds called. Amsden by other investigators that are above the limestone beds referred by him to Chester? age. Geologists generally have not followed this suggestion, but it is used in figure I to illustrate various types of usage. The lower beds of the Amsden, as identified by most geologists, would be referred by Branson, as before stated, either to his Sacajawea formation or to the unnamed unit that he believes may be of Chester age.

SECTION IN SOUTHWESTERN WYOMING

Section 6 , figure 2 , measured by W. W. Rubey and the writer along the Covey cutoff trail in the Salt River Mountains, near Afton, Wyoming, has been selected to show features present in that part of southeastern Idaho and southwestern Wyoming where the Mississippian-Pennsylvanian boundary has been drawn along the boundary between the Brazer and the Wells formations. The many difficulties accompanying the use of this boundary as a mapping boundary in the field led Rubey to erect a new mapping unit that includes the nonresistant and alternating thin beds that occur in both the lower part of the Wells and the upper part of the Brazer. A silty sandstone in the lower part of this unit may be the Darwin sandstone, or a lenticular sandstone other than the Darwin. Mississippian fossils, including Diaphragmus elegans (Norwood and Pratten) n. var., Camarophoria cf. C. explanata (McChesney), and Linoproductus ovatus (Hall), were collected from a zone in a massive limestone about 400 feet above the base of the nonresistant unit, and Chaetetes milleporaceus Milne-Edwards and Haime and other Pennsylvanian fossils, including a new species of Orthotetina that appears to be represented in the western United States only in Pennsylvanian or Permian rocks, from the beds immediately above the massive limestones. Specimens of a species of Lithostrotionella occur at the same zone as the D. elegans mentioned above. The lists of fossils identified in I93I and 1932 from this section will be published in full in W. W. Rubey's report.

\section{MORGAN LIMESTONE AREA}

The Morgan formation is typically exposed in Weber Canyon near the town of Morgan, Utah, where, in I935, the writer measured a section including the Morgan, Brazer, and Weber formations (1936). The section has not been published because it seemed preferable to await detailed mapping to determine the extent and nature of the probable faulting. Girty had measured a section there some years before. The fossils collected during both investigations are being studied, but the studies have not been completed. A casual inspection of the col- 
lections definitely confirms the statement of Blackwelder that the Morgan is, in part, of Pennsylvanian age. It has not been definitely determined whether Mississippian beds occur in the lower part of the Morgan. If the lower boundary of the Morgan is drawn on the basis of fossils and its age stated as Pennsylvanian, then, of course, Mississippian beds would be excluded from it. If, however, it is drawn on a lithologic basis that includes all beds in the nonresistant unit, then Mississippian beds might be present.

Since the writer's section was measured, A. J. Eardley (1944) has mapped in this area, and J. Stewart Williams (I943, p. 607) has published a description of the Morgan at the type area, where he found it to be $\mathrm{I}, 060$ feet thick.

The Morgan formation has been extended south and east from the type area. Calkins and Butler (I943, p. 28) referred beds in the Cottonwood-American Fork area, Utah, to the Morgan(?). Others who have recognized the Morgan outside the type area include J. Stewart Williams (1943); Thomas, McCann, and Raman (I945); Huddle and McCann (1947a); McCann, Raman, and Henbest (1946); K. G. Brill, Jr. (1944); and Kinney and Rominger (1947).

The beds identified as Morgan by the above geologists vary considerably in lithology, and one might well ask whether it is advisable to carry the name Morgan so far afield. Thompson (I945, p. 3I) has applied a new name, Hells Canyon formation, to beds in the Uintas that may be of Morgan age. Possibly his Younghall formation is equivalent to some part of the Morgan.

SECTION NEAR TABIONA, UTAH

Section 7 , figure 2 , is taken from a paper by Huddle and McCann (1947b). At this locality the Morgan formation is divided on lithologic grounds into an upper and a lower unit. The contact of the formation with the overlying Weber is drawn at the place where the sandstones cease to be dominantly red. This coincides generally, but not precisely, with the beginning of the massive, coarser sandstones and the termination of soft silty and shaly sandstones. Red and purple sandstones and shales and red cherts occur in the dominantly nonresistant lower part of the Morgan. The Mississippian-Pennsylvanian boundary is placed at the top of a black shale from which the writer has identified fossils as Mississippian. Fossils from the lower part of the Morgan, above the black shale, that have so far been studied by the writer are either too incomplete or of types too generalized and long ranging to indicate a definite age determination, but they suggest Pennsylvanian age.

\section{SECTION NEAR VERNAL, UTAH}

Section 8, figure 2, near Vernal, Utah, is condensed and generalized from a section, mostly along Ashley Creek, measured by D. M. Kinney and J. F. Rominger (I947) in the Whiterocks RiverAshley Creek area on the south flank of the Uinta Mountains, Utah.

As in the Tabiona region farther west, the Mississippian-Pennsylvanian boundary is placed at the top of a black shale, but the black shale is not so well exposed as in the Tabiona region. The Morgan is divided into two parts, both of which are tentatively considered to be of Pennsylvanian age. The collections need to be carefully studied, however, as they contain many forms that are generalized. The lower part of the Morgan is mostly limestone and is more resistant than at other localities where shales and sandstones are intercalated at short intervals. The upper part consists of three subdivisions, the lowest of which is mainly soft red shale, sandstone, or sandy shale. 
It probably corresponds approximately to the upper unit of the Morgan in the area near Tabiona. The middle subdivision of the upper part of the Morgan is mainly hard buff to red sandstones, and the upper subdivision is tan limy sandstones and gray cherty limestones. It appears to the writer that the upper and middle subdivisions probably correspond to at least part of the beds considered to be Weber in the Tabiona region. The upper contact of the Morgan is drawn at the top of the highest limestone bed.

Stratigraphic sections here and in near-by parts of the Uintas have been made at or near the same localities as those already discussed by several geologists. The information in these separate investigations needs to be better integrated than it is at present, and work is now in progress to that end.

\section{SECTION IN STOCKTON-FAIRFIELD AREA, UTAH}

Section 9 of figure 2, condensed from one given by Gilluly (I932, p. 3I) from Soldier Canyon near Stockton, was selected to show features existing in an area where the Mississippian-Pennsylvanian boundary is within the Manning Canyon shale.

Both the upper and the lower contacts of the Manning Canyon shale are gradational. Gilluly places the upper contact, with the Oquirrh formation, at the point where the limestones start to become more abundant than shales. The lower contact is drawn where shales become more abundant than limestones. The Manning Canyon, in contrast to other formations farther north that include the Mississippian-Pennsylvanian boundary, is almost devoid of red beds. Mississippian (Chester) fossils occur about 500 feet above the base of the Manning Canyon, and Pennsylvanian fossils occur about 350 feet higher. These are listed in Gilluly's report.

The Manning Canyon shale has been recognized at various places in northcentral Utah. A section showing the Manning Canyon shale in the Wasatch Mountains area near Provo is given by Baker (1947). Nolan (I935, p. 31) described the Manning Canyon of the Gold Hill area, central western Utah. Bissell and Hansen in 1935 (p. 163) discussed briefly the gradational character of the Mississippian-Pennsylvanian contact in Spring Creek Canyon, east of Springville, Utah.

\section{PROBLEMS IN PALEONTOLOGY}

NEED FOR MORE PALEONTOLOGICAL DATA

The need for more paleontologic data is definitely shown in the preceding discussions of the few selected stratigraphic sections. Not only is the need for additional and larger collections from certain zones indicated, but there is also shown a need for more studies and better integration of collections already made. The problem of additional collections from specific zones in critical areas is not everywhere easily solved. In many mountain ranges the Carboniferous rocks are exposed mainly in areas of high altitude that are difficult of access. Furthermore, many of the beds are either unfossiliferous or contain very few fossils. Some beds that have fossils do not yield them readily, and it is difficult to obtain specimens that are well enough preserved to permit definite identifications. When closely related genera and species differ from one another only in some small internal character or in some particular type of ornamentation, as many do, large collections are frequently required to provide specimens to show adequately these characters.

If one could everywhere determine the 
age of a formation or parts of a formation by making collections from a few localities known to provide good material, the problem would be simplified. Collections definitely located geographically and stratigraphically from many widespread areas are, however, needed to determine the age ranges of formations. The determination of the stratigraphic positions of collections in the Rocky Mountain region is frequently a problem because of faulting and folding. Especially are so-called "bedding-plane faults" likely to be missed and duplications or omissions of strata unnoticed. Stratigraphic sections and the fossil collections from these sections, in the Rocky Mountain and Great Basin areas especially, are, as a rule, on much firmer ground if the stratigraphic work is done in connection with rather detailed mapping.

\section{SPECIES DIFFERENTIATION}

Studies in systematic paleontology that deal with the relationships of the species of several genera need to be made. These should be made by paleontologists who have available large numbers of specimens, stratigraphically and geographically well located. Only by the study of large collections can differences between two individuals be correctly evaluated, that is, whether they are individual, varietal, specific, subgeneric, or generic. Extensive experience in applying zoölogical concepts in classification to closely related forms may substitute in part for the lack of large collections. The mere presence of some differences from a type specimen of a species does not, as all paleontologists know, constitute reasons for specific, or even varietal, differentiation. The ranges of variation within several species of the Rocky Mountain area need to be determined.

In the Rocky Mountain Carbonifer- ous, certain individuals of the Pennsylvanian Spirifer occidentalis-rockymontanus group so closely resemble individuals of the Mississippian S. increbescenskeokuk group, as identified in the West, that one is forced to the conclusion that, if these species have been correctly identified, they either overlap or are not distinct species. Studies of western representatives of this group based on large, definitely located collections need to be made. The nomenclature should reflect as nearly as possible the actual relationships, and if in any instance it is desirable to combine two or more groups considered species into one, then that combination should be made. This would serve the cause of stratigraphic paleontology more than maintaining fictional differences would. Progress in paleontology, it is true, is made by finer and finer subdivisions, if they are truly useful, but progress is also made by combining socalled "species." It is frequently true that, when only a few specimens are known, several apparent species can be distinguished, whereas in larger collections species lines disappear and fewer species are recognizable.

Similar investigations need to be made of Mississippian and Pennsylvanian species of the genera Composita, Chonetes, Lithostrotionella, Reticulariina, Linoproductus, and others.

\section{USE OF FOSSILS IN CORRELATIONS}

One of the most important problems in the use of fossils for correlation in the Carboniferous of the Rocky Mountain region has just been discussed. More needs to be known about the ranges in variation within certain common species and about effective criteria for distinguishing these species, if they are distinct. Another problem that has also been mentioned lies in the difficulty of obtain- 
ing large collections of well-preserved materials at critical localities and at critical stratigraphic zones. Criticism has been made of lists of fossils that contain many question marks and provisional identifications, but species cannot be positively identified when the diagnostic characters are not preserved. Correlations can rarely be positively made if species or genera cannot be definitely identified.

Not all species in the Mississippian and Pennsylvanian rocks in the Rocky Mountain region are long ranging or generalized. Some are distinct and are of definite stratigraphic value, along with other evidence, in the correlation of beds and zones. They have been called "index fossils," " but the writer hesitates to use this term because too many fossils are index fossils only as long as relatively little is known about them. Since the writer first began paleontological work in the West, the range of many so-called "index fossils" has been extended so that they can no longer be used in the restricted sense of the term. One of these is Archimedes. For many years it was considered an index of certain zones in the Mississippian in this country; but in 1927 Girty and Gilluly (I932) discovered it above Chonetes mesolobus (Mesolobus mesolobus of recent authors) in the Oquirrh Mountains, Utah; and it has since been discovered in many places in Pennsylvanian rocks in the West and in the Permian in Russia. Other fossils, to mention a few, that have lost their early meaning as index fossils, within the

${ }^{2}$ An "index fossil" is generally defined as one that is characteristic of a specified time unit, more or less irrespective of facies, whereas a "facies fossil" is defined as being characteristic of a certain facies and crossing one or more time boundaries. In the larger aspect, of course, all fossils are index fossils and all fossils are probably facies fossils, but most geologists define and use the terms in the more restricted sense. writer's experience, include Lithostrotion (or Lithostrotionella), Caninia, Leptaena analoga (Phillips), Leiorhynchus carboniferum Girty, Reticulariina spinosa (Norwood and Pratten), and Millerella.

Few paleontologists have ever considered correlations in the Rocky Mountain Carboniferous that were based solely on one or two index fossils to be more than temporary, nor have they postulated the presence or absence of beds or zones on a similar basis. In using index fossils, the possibility always exists that the ranges of these fossils may be extended, and it is preferable to use several types of fossil evidence, where possible, for every correlation. Whole faunas are decidedly more useful in making correlations than are conclusions based on several index fossils or on fossils of any one class.

The province of this paper does not permit an exhaustive discussion of the various uses of fossils in correlation or the theories behind these uses. Paleontologists working on late Paleozoic rocks in the Rocky Mountains are generally aware of the many complex problems in any correlation and are usually on the alert for influences of less obvious factors. For instance, in parts of the Rocky Mountain region certain types or classes of fossils are relatively common in specific types of lithology and nearly absent in others - to cite one example, the large horn corals of the crystalline limestones of the Brazer. The possibility is always kept in mind that these corals are absent at certain stratigraphic zones merely because of ecological conditions (to be discussed more fully later). Another example: certain types or classes of fossils, such as crinoids and cephalopods, are relatively rare, and it is possible that their assumed excellence as zone markers is enhanced by their rareness. Still another example: several Mid-Continent 
species have been identified in the Rocky Mountains, and it is possible that some of these species migrated into the Rocky Mountains so slowly that they occur there at a later time than in the MidContinent region. The possibility is kept in mind that the absences of species from certain zones may mean only inadequate collecting; also that classes of fossils only recently recognized and as yet little known may yield results that appear to be more definite than if they were better known. The value of relative abundance of specific forms in making local correlations has for a long time been realized and utilized in the Western states.

Not only do paleontologists use comparisons of total faunas and combinations of index fossils for correlations, but the reported first appearances of new forms and the reported extinctions of old forms are sometimes given special consideration. Certain evolutionary stages in specific species and especially genera, if adequately tested, and certain trends in evolution, if firmly established, are also used. An example of this last is the tendency for coarsely plicated Spirifers of the rockymontanus type to develop prominently in the middle Mississippian and to die out at the top of the lower Pennsylvanian (Des Moines equivalent). It is realized that whole faunas may transgress time lines, but such transgressions are relatively unimportant in correlations within local areas.

\section{ZONATION}

For many years rocks of Chester age have been generally separated from rocks of older Mississippian age throughout the northern and central Rocky Mountain area, and certain Mid-Continent zones have been recognized within the preChester Mississippian rocks in several local areas. As early as 1873 , Meek (p.
433) published a notice of a fauna from beds that he assigned to the Spergen limestone, which was then considered part of the St. Louis limestone, and that are probably now included in the Madison limestone in Montana. The presence of a zone of St. Louis or Meramec age in the Mississippian rocks of the Rocky Mountains has been mentioned in print by Willis (pp. 316,324$)$ in 1902 (St. Louis fossils identified by Stuart Weller in the Yakinikak limestone of Willis in northwestern Montana); by Girty (1927, p. 7I), both published and unpublished; by Sloss and Laird in I945; and by several others. The writer and others have recognized it in the field at several places where its presence has not been mentioned in published accounts. Other zones in the Mississippian that correspond to pre-Chester Mississippian zones in the Mid-Continent area have been recognized in local areas.

In 1927 , in a general summary of the Mississippian rocks of southeastern Idaho, Girty (p. 7I) recognized affinities of different faunules from the Brazer with those from the Spergen, St. Louis, and Chester strata. He realized, however, that the Spergen fauna may be a facies fauna rather than one that can be definitely correlated with the typical Spergen. The writer in 1935 and also in later years measured and collected from many stratigraphic sections in an effort to fix these and possibly other zones in the Brazer, as well as to determine possible zones in the Wells and Phosphoria formations. J. Stewart Williams and J. S. Yolton in 1945 recognized five zones in the Brazer limestone as exposed at Dry Lake, Utah. The lowest zone was correlated by them with the Warsaw formation and the next highest zone with higher beds in the Meramec group, possibly with the St. Louis limestone. Their 
third highest zone is considered by them to be transitional between the Meramec and Chester groups, and the two upper zones are Chester. Most of the Chester forms cited by them are generalized forms that have not only a considerable stratigraphic range in the Chester but occur or are represented by very closely related forms both in younger and in older rocks. One exception, however, is Diaphragmus elegans (Norwood and Pratten). The proposed correlation of Branson's Sacajawea formation (lower Amsden of most authors) with MidContinent beds and of the units of the Big Snowy group with specific units in the Chester of the Mid-Continent has been discussed before.

On the Pennsylvanian side of the Mississippian-Pennsylvanian boundary, a zone of post-Morrow-pre-Kansas City age has been recognized widely for a long time. The zone was first recognized and identified widely by megafaunas (Williams, in Moore, I944); but fusulinids attesting to its existence were also identified by Girty prior to I927. During recent years fusulinids from the Quadrant formation of Montana, the upper part of the Amsden and Tensleep of Wyoming, the Wells formation of Idaho and Utah, the Oquirrh of Utah, and other formations in neighboring states have supplemented and confirmed the evidence from the larger invertebrates. Although some efforts have been made to divide this zone into two - a lower Lampasas and an upper Des Moines-it has not proved feasible on the basis of the megafossils. Some fusulinid workers also have not found such a division practicable.

Correlation of Lower Pennsylvanian beds with the Pennsylvanian formations of the Appalachian region rather than directly with the formations of the MidContinent areas was attempted by G. H.
Girty in several written opinions, and he has identified, more or less provisionally, beds of Pottsville and post-Pottsville age. The writer does not believe that these correlations, when based on invertebrate megafossils, were very reliable as to detail, and Girty appears not to have considered them very reliable. In 1934, C. B. Read described a Pottsville flora, probably of middle Pottsville age, from beds exposed near Leadville, Colorado, from which Girty had described a macrofauna that he believed represented a zone that was "very early in Pennsylvanian time and probably older than any beds of the Kansas and Nebraska section." Read regarded this flora as older than the Glen Eyrie flora.

During the last five or six years, beds thought to be immediately above the Mississippian-Pennsylvanian boundary have been referred to a zone that is considered the equivalent of the Morrow of the Mid-Continent. Most of these references have been based mainly on fusulinid evidence. In general, the larger invertebrate fossils, where they are present, do not give adequate evidence-if, in fact, any positive evidence at all-for distinguishing the so-called "Morrow zone" from the zones bearing both Des Moines-Lampasas macrofossils and microfossils. This does not necessarily mean, however, that larger collections may not provide material whereby such a zone can be recognized by larger fossils.

L. G. Henbest (I946) seems to have been the first actually to designate beds in the area under discussion as of Morrow age, but the presence of very early Pennsylvanian beds in near-by areas had been noted before by C. B. Read, G. H. Girty, the writer (1944, p. 700), and others, and M. L. Thompson (1936) had previously suggested the presence of beds of Morrow age in the Black Hills. Paleon- 
tologists had also identified a zone principally in the subsurface that they called "Morrow" in other parts of the general Rocky Mountain area, namely, New Mexico and Colorado. M. L. Thompson (I945) identified a zone correlated by him with the Morrow over a wide area in the Uinta Mountains; Williams and Yolton (I945, p. I I 52). referred rocks in central-northern Utah to the Morrow; Thomas, McCann, and Raman (1945) referred rocks in northwestern Colorado and northeastern Utah to the Morrow; and H. W. Scott (I945, p. I I95) referred rocks in the sequence which he had identified as Amsden in central Montana to the Morrow.

In assigning rocks to the Morrow, Henbest appears to have laid considerable stress on the occurrence in them of the fusulinid genus Millerella, which was once thought to be restricted to rocks of Morrow age; but the range of Millerella is now generally considered to extend from late Mississippian to late Pennsylvanian time. Thompson recognizes the long range of the genus Millerella in Pennsylvanian rocks and the difficulty of using species of Millerella to denote different stratigraphic zones. He identifies his zone of Millerella, which zone name he applies to rocks of Morrow age, by the predominance of specimens of Millerella and the absence of the more highly developed fusulinids with which Millerella is commonly associated in Pennsylvanian rocks of post-Morrow age. Williams and Yolton base their assignment of beds to a Morrow age mainly on microscopic bryozoans and ostracodes identified by Chalmer L. Cooper. They also list larger fossils, but nearly all the larger fossils are forms which, if identifiable, have been collected elsewhere in beds associated with fusulinids of younger age than Morrow. Scott bases his age de- termination on Millerella, with supplementary evidence from other microscopic forms.

Despite the recognition of beds at the places mentioned above and at other places in the northern and central Rocky Mountains, correlated with faunal zones in the Mid-Continent, zonation studies useful over wide areas in the rocks near the Mississippian-Pennsylvanian boundary have not been published. One reason for this deficiency is the paucity of fossils and the poor preservation in many beds. Large collections of good fossils from many zones and localities are needed if zonation is to be based on trustworthy grounds. Another reason is the great number of relatively generalized longranging species. Still another reason is that faunal zones do not coincide in many instances with lithologic divisions, as they more or less do in some places. This reduces the general use and recognition of faunal zones in areas where the natural mapping units are not also faunal units.

In the Rocky Mountain area there are great thicknesses of rather uniform lithology, especially in the Mississippian rocks. This contrasts with the situation in the Mississippi Valley, where comparatively frequent alternations in deposition have occurred and where, consequently, the typical formations are thinner lithologic units. The Mississippian faunas in the Mississippi Valley were thus subjected to more frequent changes of conditions than were those in the Rocky Mountain area. Both the Mississippian and the Pennsylvanian rocks of the Mid-Continent were deposited in a different basin (though there were connections) than the one in which the rocks of the same approximate ages in the Rocky Mountain region were deposited. Although some species have been identified as Mid-Continent species, the faunas 
in general are quite different. Most correlations of zones in the Rocky Mountains with zones in the Mid-Continent, when made in detail, have appeared based upon inadequate evidence. The writer has believed for a long time that either the southeastern Idaho section or one of the sections in central Utah in an area that has been mapped in detail and from which a great many collections have been made should be selected as a Rocky Mountain standard and that correlations in this region should be made in terms of this standard rather than in terms of Mid-Continent standards. There seems no reason to suppose that in this different basin the ranges of fossils would be precisely the same as in the Mid-Continent basin or basins. Broad correlations can be made, but only broad ones are justified at the present. Several instances are on record of ranges of Mid-Continent species, and even of genera, that are different from ranges in the Mid-Continent.

\section{STRATIGRAPHIC PROBLEMS}

CRITERIA FOR FORMATIONS

A study of the selected stratigraphic sections discussed on pages $33 \mathrm{I}-34 \mathrm{O}$ shows that a considerable variety of criteria has been used for the definition and delimitation of formations near the Mississippian-Pennsylvanian boundary in the northern and central Rocky Mountain region. These criteria have given quite different results concerning the content and thickness of a formation in the same or in near-by regions. Most geologists have used lithologic criteria, but many have combined lithologic criteria with structural relations, such as unconformities, karst surfaces, or brecciation, or with faunal data. In some instances the location of an unconformity or the boundary of a faunal zone seems to have been the determining factor in the separation of one formation from another, and the lithologic change at the boundary only secondary. Few geologists defi nitely state that the basis for their formation boundaries is faunal, but those who refuse to put Mississippian beds in the same formation with Pennsylvanian beds, simply because of this difference in age, are nevertheless using faunal data as their main criterion.

Even those who have used lithologic composition as the main factor in the definition of their formations have not agreed on the type of lithologic criteria to use. It is probably unlikely that absolute uniformity in usage will ever be attained over wide areas or in different sections of the country; and it probably is not desirable. Geologists as a rule will use whatever they find in the particular region that provides mappable units, and the choice will depend not only on individual preferences but also on the character of the topography and climate of the particular area, the lithology of the rocks, and other factors.

In work in the Rocky Mountain region, the writer has been impressed with the usefulness of lithologic formations based upon features of the total lithologic composition of the formation more than that of formations based on the presence of some specific color; or on the highest or lowest occurrence of some particular type of lithology, such as the highest limestone or the lowest phosphate bed; or on the tracing of some conspicuous bed, such as a sandstone; or on the tracing of unconformities, either by faunal data or by matching unconformities seen in separate outcrops. Nearly all these criteria have been, or are being, used in the Rocky Mountain area, and local conditions might make any one of them more desirable than the others. The first ap- 
pearance of a changed type of lithology especially has cogent arguments in its support.

Far more important than the adoption of any one particular type of criterion is the desirability of uniform usage, at least in local areas, to which, after all, formation names only apply.

During recent years detailed stratigraphic work and subsurface work have greatly increased in the Rocky Mountain area. This work has added much needed detailed knowledge regarding the individual beds that make up the formations and has resulted, in some areas, in the breaking-up of larger formations and the giving of formational rank to units that constituted subdivisions or merely unrecognized parts of the larger formations. In the writer's opinion, new and thinner formations are desirable if, and wherever, they conform to the generally accepted criterion that a formation "shall... meet the practical and scientific needs of the users of geologic maps" (Ashley et al., I933, p. 43I). As stated in the remarks accompanying the stratigraphic code just quoted, "practicability of mapping is usually an essential feature" of a formation. It is only "under exceptional conditions" that this criterion should be waived. The test of the validity of new formations proposed for use in rocks of Carboniferous age in the Rocky Mountain area, whether surface or subsurface formations, would, in the writer's opinion, lie in the decision as to whether or not they could reasonably be supposed to form practical mapping units, under the conditions existing in the region at the present time, if exposed over a considerable area. The validity of any surface formation can be tested by mapping. Ample terminology exists for the recognition and designation of lithologic units below the rank of formation, so that distinc- tions as close as are desired can be recognized by some sort of designation. As indicated in the remarks explaining features of the code, formations may include parts of two systems or even major unconformities where there is a sequence of similar beds and where in practical work it is not useful to make a division.

Much has been written about the necessity of distinguishing between rock and time (or so-called "time") units in stratigraphic nomenclature, and interest in this question has been revived lately because of many examples of widespread confusion and because a third categorytime-rock units-has been proposed. It is not appropriate to discuss this question here, but a satisfactory understanding of these differences, if agreed upon, would aid in achieving more uniformity in usage in some parts of the Rocky Mountains.

\section{UNCONFORMITIES}

Unconformities exist between and within several formations that occur near the Mississippian-Pennsylvanian boundary in the northern and central Rocky Mountains. Many of these are discussed in connection with the different stratigraphic sections, to which the reader is referred, but additional data on many of the unconformities are in publications from which no sections were selected or in the writer's files and notes.

Williams and Yolton (1945, p. II 50) show a widespread unconformity at the base of the Meramec division. Unconformities in local areas at this stratigraphic zone have been mentioned by others. A widespread unconformity occurs at the top of the Madison limestone over a wide area. The writer believes that this is mainly a pre-Chester or pre-Ste. Genevieve unconformity. In some places in Montana and Wyoming, beds that have been considered as young as St. 
Louis in age have been included in the Madison; but in other places the upper part of the Madison limestone is of Osage age. The disagreement regarding the age of the Madison is beyond the scope of the present paper. Some of the disagreement may be due to a difference in interpretation of the boundaries of formations and groups in the Mississippi Valley, with which correlations have been attempted. An unconformity and overlap between the Heath and the Amsden formations that may be within the Chester has been described from Montana, but the age of the unconformity depends on the age assigned to the Amsden there. An unconformity occurs beneath the Darwin sandstone unit at some places where it has been identified in Wyoming. Unconformities have been placed at the Mississippian-Pennsylvanian boundary as delimited by fossils mainly because it appears that in some places fossil zones of the Mississippi Valley Basin are not represented here. Lithologic criteria that suggest terrestrial beds and other types of lithologic criteria indicate unconformities at various places in the Amsden formation, some of which are probably very local in extent.

\section{PROBLEMS IN ECOLOGY AND PALEOGEOGRAPHY}

Problems in ecology and paleogeography that are as challenging as those in paleontology and stratigraphy occur in the Carboniferous rocks of the northern and central Rocky Mountains. Mention may be made of a few. The occurrence in these rocks of black shales, dwarf faunas, oölitic limestones, great thicknesses of crystalline limestones containing few fossils other than corals, alternating terrestrial and marine beds, considerable thicknesses of red beds, finely laminated limestones, gypsums, and cross-bedded quartzites suggests the wide range of ecological conditions that existed during late Mississippian and early Pennsylvanian time. These also indicate the variety of ecological problems.

Existing data on the paleogeography need to be consolidated and published and new data added. Geosynclinal and shelf areas have been indicated in parts of the area. The location of major land masses is known in a general way, but details of the paleogeography, including precise locations and extent of major features, are not known. Relationships to other areas, such as the Mid-Continent and Pacific Coast areas, need to be more definitely worked out and sea connections more precisely located. Much additional data are needed on sources of sediments. Additional isopach maps need to be constructed; but these, to be widely understood, either will have to await unification of some of the stratigraphic terminology or will have to be accompanied by considerable stratigraphy, explaining the author's usages of formations.

Of quite a number of recent articles containing maps or discussions of paleogeographic features, papers by Nolan (1943) and Eardley (1947) are especially comprehensive and significant and contain valuable references to other literature.

\section{CONCLUSIONS}

I. As elsewhere in the United States, many unsolved problems are presented by rocks at and near the MississippianPennsylvanian boundary in the northern and central Rocky Mountains.

2. The problems cover various phases of stratigraphy, systematic paleontology, stratigraphic paleontology, ecology, and paleogeography.

3. Adequate collections of well-pre- 
served fossils are needed from critical stratigraphic zones at critical localities. Collecting has been limited in some places by the absence of marine invertebrates due to unfavorable conditions either during the deposition of the beds or for the preservation as fossils. At some other places it is limited by the difficulty of separating fossils from the enclosing rock. At many places, however, the small collections made have shown that more time and more experience in collecting would have yielded the larger and more varied collections needed.

4. The considerable amount of paleontologic data already obtained should be better organized for effective use.

5. Critical paleontologic studies of several common species are essential. These should be based on enough specimens to show the range of variation within each species. Species that are too narrow because of the lack of knowledge of the range of individual variation encourage erroneous and unsubstantiated correlations. Species that are too broad contribute to the difficulty of establishing recognizable paleontologic zones. The fact that certain species definitely are long ranging and do not contribute effectively to detailed zonation studies should be recognized and the nomenclature adjusted accordingly.

6. Paleontologic correlations should be based on several lines of evidence. Index fossils are very useful in combination with one another and with other faunal data, but changes in the stratigraphic ranges of some so-called "index fossils" argue for caution in the use of all of them. Correlation data from one class of fossils need to be checked against those from other classes wherever possible. No one class is of itself totally sufficient.

7. Correlations of restricted paleontologic zones in the Rocky Mountains with zones in the Mid-Continent region based on evidence from larger invertebrate fossils have in several instances been made on data that are inadequate in both places.

8. Detailed correlations within the Rocky Mountain area should be made mainly with typical sections within that area. There is little reason to believe that the Rocky Mountain and Mid-Continent areas, being distinct, though in places connected, basins, had the same geologic history. Nor did they necessarily have the same faunal zones, if one uses the term "zone" in a restricted sense, or precisely the same ranges of species. The gross differences in the faunas suggest that the ranges of species may, in fact, be quite different.

9. The use of fossils in determining the relative ages of beds in the Carboniferous of the Rocky Mountain area has been extensive and, despite the deficiencies of the data at some places, appear to have been as successful, though perhaps not so detailed, as in most other areas. Many hundreds of collections have been studied, and the age conclusions based upon these studies have been given to field men for further work. Many hundreds of square miles involving Mississippian and Pennsylvanian rocks have been mapped in detail, and some areas have been remapped on different scales. Many areas have been complexly folded and faulted, and other areas have been highly metamorphosed. Yet detailed remapping of some areas and mapping of neighboring areas have changed few of the paleontological age determinations.

Io. Formations have been defined and their limits set by many different criteria. More uniformity than now exists, as to both criteria and terminology, is desirable. A big step toward uniformity would result from general agreement to 
define and actually employ formations, whether surface or subsurface, as lithologic units which could be effectively mapped, or could logically be supposed to be mappable, on the ordinary scales of topographic quadrangle mapping used in the area where they occur. Smaller units could be given varying degrees of subformational rank to allow as fine discrimination as desired. Such a definition would not prohibit formations from containing unconformities, parts of two geologic systems, or several paleontologic zones or from varying somewhat in age from place to place. Even with such a general agreement, problems regarding the details of the lithologic composition of various formations, lateral gradation, and other points would remain to be solved.

II. Additional work on the Carboniferous rocks and their faunas in the Rocky Mountain area should be very thorough and detailed, or frankly interpretive in localities for which the data are inadequate. All types of previous knowledge should be utilized. Reconnaissance work has been done in nearly all areas.

I 2. The combination of detailed stratigraphic and paleontologic work with detailed mapping offers the best possibility of obtaining adequate and reliable data needed from the northern and central Rocky Mountain region.

\section{REFERENCES CITED}

Ashley, G. H., et al (1933) Classification and nomenclature of rock units: Geol. Soc. America Bull. 44, pp. 423-459.

BAKER, A. A. (I947) Stratigraphy of the Wasatch Mountains in the vicinity of Provo, Utah: U.S. Geol. Survey Oil and Gas Inv. Preliminary Chart 30.

Bissell, H. J., and Hansen, G. H. (I935) The Mississippian-Pennsylvanian contact in the central Wasatch Mountains, Utah: Utah Acad. Sci. Proc., vol. I 2 , p. I63.

Blackwelder, Eliot (igio) New light on the geology of the Wasatch Mountains, Utah: Geol. Soc. America Bull. 21, pp. 517-542.

- (19I3) New or little known Paleozoic faunas from Wyoming and Idaho: Am. Jour. Sci., 4th ser., vol. 36 , pp. I 74-1 79 .

Branson, C. C. (I937) Stratigraphy and fauna of the Sacajawea formation, Mississippian, of Wyoming: Jour. Paleontology, vol. i I, pp. 650-66o.

- (r939) Pennsylvanian formations of central Wyoming: Geol. Soc. America Bull. 50, pp. II $99-1225$.

Branson, E. B., and Greger, D. K. (Igir) Amsden formation of the east slope of the Wind River Mountains of Wyoming and its fauna: Geol. Soc. America Bull. 29, pp. 309-326.

BrILl, K. G., Jr. (I944) Late Paleozoic stratigraphy, west-central and northwestern Colorado: Geol. Soc. America Bull. 55, pp. 621-655.

Calkins, F. C., and Butrer, B. S. (1943) Geology and ore deposits of the Cottonwood-American Fork area, Utah: U.S. Geol. Survey Prof. Paper $2 \mathrm{CI}$.
Croneis, C. G., and Funkhauser, H. J. (I938) New ostracodes from the Clore formation [IIl.]: Denison Univ. Bull. 38 , no. Io (Sci. Lab. Jour., vol. 33, art. 7), pp. 331-36o.

Darton, N. H. (I904) Comparison of the stratigraphy of the Black Hills, Big Horn Mountains and Rocky Mountain front range: Geol. Soc. America Bull. I5, pp. 379-448.

- (1906) Description of the Bald Mountain and Dayton quadrangles, Wyoming: U.S. Geol. Survey Geol. Atlas, Bald Mountain-Dayton Folio I4I.

EARDLEY, A. J. (1944) Geology of the north-central Wasatch Mountains, Utah: Geol. Soc. America Bull. 55, pp. 8r $9-894$.

—_ (I947) Paleozoic Cordilleran geosyncline and related orogeny: Jour. Geology, vol. 55, pp. 309-342.

Foster, H. L. (1947) Paleozoic and Mesozoic stratigraphy of northern Gros Ventre Mountains and Mount Leidy Highlands, Teton County, Wyoming: Am. Assoc. Petroleum Geologists Bull. 31, pp. 1537-1 593 .

Gardner, L. S.; Hendricks, T. A.; Hadley, H. D.; and Rogers, C. P., Jr. (I945) Columnar sections of Mesozoic and Paleozoic rocks in the mountains of south-central Montana: U.S. Geol. Survey Oil and Gas Inv. Preliminary Chart i 8 (also published as Stratigraphic sections of Upper Paleozoic and Mesozoic rocks in southcentral Montana, with description of fauna of Amsden and Heath formations by L. L. Sloss: Montana Bur. Mines and Geology Mem. 24, I946). 
Gilluly, James (I932) Geology and ore deposits of the Stockton and Fairfield quadrangles, Utah: U.S. Geol. Survey Prof. Paper I 73.

Girty, G. H. (1927) In Mansfield, G. R., Geography, geology, and mineral resources of part of southeastern Idaho: U.S. Geol. Survey Prof. Paper I52.

Henbest, L. G. (I946) Correlation of the marine Pennsylvanian rocks of northern New Mexico and western Colorado (abstr.): Washington Acad. Sci. Jour., vol. 36, p. I34.

Huddle, J. W., and McCann, F. T. (r947a) Geologic map of Duchesne River area, Wasatch and Duchesne counties, Utah: U.S. Geol. Survey Oil and Gas Inv. Preliminary Map 75. $(1947 b)$ Late Paleozoic rocks exposed in the Duchesne River area, Duchesne County, Utah: U.S. Geol. Survey Circ. I6.

Kinney, D. M., and Rominger, J. F. (I947) Geology of the Whiterocks River-Ashley Creek area, Uintah County, Utah: U.S. Geol. Survey Oil and Gas Inv. Preliminary Map 82.

McCann, F. T.; Raman, N. D.; and Henbest, L. G. (I946) Section of Morgan formation, Pennsylvanian, at Split Mountain in Dinosaur National Monument, Uintah County, Utah: U.S. Geol. Survey Mimeographed Rept., I946.

MeEk, F. B. (I873) Preliminary paleontological report, consisting of lists and descriptions of fossils, with remarks on the ages of the rocks in which they were found: U.S. Geol. and Geog. Survey Terr. 6th Ann. Rept., pp. 429-518.

Morey, P. S. (I935) Ostracoda from the Amsden formation of Wyoming: Jour. Paleontology, vol. 9, pp. 474-482.

Nolan, T. B. (I935) The Gold Hill mining district, Utah: U.S. Geol. Survey Prof. Paper 177.

- (1943) The Basin and Range Province in Utah, Nevada, and California: U.S. Geol. Survey Prof. Paper 197-D, pp. 141-196.

Perry, E. S., and Sloss, L. L. (1943) Big Snowy group, lithology and correlation in the northern Great Plains: Am. Assoc. Petroleum Geologists Bull. 27, pp. I 287-I304.

READ, C. B. (I934) A flora of Pottsville age from the Mosquito Range, Colorado: U.S. Geol. Survey Prof. Paper 185-D, pp. 79-96.
Reeves, Frank (I93I) Geology of the Big Snowy Mountains, Montana: U.S. Geol. Survey Prof. Paper I65, pp. I35-149.

ScotT, H. W. (I935) Some Carboniferous stratigraphy in Montana and northwestern Wyoming: Jour. Geology, vol. 43, pp. IOII-IO32.

(1945a) Age of the Amsden formation (abstr.): Geol. Soc. America Bull. 56, p. i ig6.

$\left(1945^{b}\right)$ Pennsylvanian stratigraphy in Montana and northern Wyoming (abstr.): ibid., p. IIg6.

Sloss, L. L. and LAIRD, W. M. (I945) Mississippian and Devonian stratigraphy of northwestern Montana: U.S. Geol. Survey Oil and Gas Inv. Preliminary Chart I 5 .

Thomas, C. R.; McCann, F. T.; and Raman, N. D. (1945) Mesozoic and Paleozoic stratigraphy in northwestern Colorado and northeastern Utah: U.S. Geol. Survey Oil and Gas Inv. Preliminary Chart I6.

Thompson, M. L. (1936) Fusulinids from the Black Hills and adjacent areas in Wyoming: Jour. Paleontology, vol. ıo, pp. 95-1 I3.

(I945) Pennsylvanian rocks and fusulinids of east Utah and northeast Colorado correlated with Kansas section: Kansas Univ. Geol. Survey Bull. 60 .

Williams, James Steele (1936) Stratigraphic section and faunules of some western Carboniferous formations at or near the type localities (abstr.): Geol. Soc. America Proc. I935, pp. I I 8-I I9.

- (r944) In Moore, R. C., et al., Correlation of Pennsylvanian formations of North America: Geol. Soc. America Bull. 55.

Williams, James Stewart (1943) Carboniferous formations of the Uinta and northern Wasatch Mountains, Utah: Geol. Soc. America Bull. 54, pp. $59 \mathrm{I}-624$.

and Yolton, J. S. (1945) Brazer (Missisippian) and lower Wells (Pennsylvanian) section at Dry Lake, Logan quadrangle, Utah: Am. Assoc. Petroleum Geologists Bull. 29, pp. I I 43-I I 55 .

Willis, BAILEY (I902) Stratigraphy and structure, Lewis and Livingston Ranges, Montana: Geol. Soc. America Bull. I3, pp. 305-352. 